\title{
Corticioid fungi (Basidiomycetes) in different biocoenoses of Byarezinski Biosphere Reserve, Belarus
}

\author{
EUGENEYURCHENKO
}

YURCHENKO, E. 2003: Corticioid fungi (Basidiomycetes) in different biocoenoses of Byarezinski Biosphere Reserve, Belarus. - Karstenia 43: 55-65. Helsinki. ISSN 0453-3402.

\begin{abstract}
In this paper distributional patterns and species composition of corticioid fungi (Corticiaceae s. 1.) in forest ecosystems of Byarezinski Reserve were studied in permanent plots. The number of species per plot varies from 6 in oligotrophic bogs (PinoLedetum) to 47 in broadleaf-spruce forests (Querco-Piceetum). The cluster analysis of species lists revealed two main groups of biocoenoses with specific assemblages of fungi: southern taiga non-swamp coniferous forest and swamp forests dominated by alder and birch. The major factors determining biocoenotic preferences and species richness of fungi are number of tree and shrub species in community, coniferous/ deciduous hosts proportion, and soil humidity.
\end{abstract}

Key words: biocoenotic distribution, broadleaf-spruce forest, Corticiaceae, permanent plot, species assemblage, species diversity, southern taiga community

Eugene Yurchenko, Laboratory of Mycology, V.F. Kuprevich Institute of Experimental Botany, Akademichnaya str. 27, BY-220072, Minsk, Belarus

E-mail: fungi@bibel.bas-net.by

\section{Introduction}

Corticioid fungi (Corticiaceae s.1.) play an important role as wood decomposers and finally participants of soil formation process in forest ecosystems over boreal and nemoral zones. Many species have small-sized or inconspicuous fruitbodies and are often overlooked in biocoenotic studies. In our definition corticioid fungi in broad sense are resupinate homobasidiomycetes lacking poroid hymenophore and it mostly corresponds with the genera described by Jülich and Stalpers (1980), including also resupinate species of Thelephoraceae and the genus Hymenochaete.

Earlier studies in Byarezinski State Biosphere Reserve (Vitsebsk and Minsk region, Belarus) on the fungi in question were done by Golovko and Komarova (1972). They published a list of 40 corticioid species.
The reserve is situated in the boreo-nemoral (mixed forests) subzone, north of Belarusian Moraine Range physiographic province and at the south border of Belarusian Paazer'e province. The reserve is entirely disposed in Upper Byarezina Lowland physiographic district (Dzyaments'eu 1975). Unlike the typical Paazer'e landscapes with greatly partitioned relief with lake complexes, the territory of the reserve consists of large plain lowlands and several small eminences. Forests occupy $635 \mathrm{~km}^{2}$ (83.3\% of the area). The main types of vegetation are large oligotrophic bogs with Pinus sylvestris L. var. nana Pall. (24.6\% of forest area), Betula pubescens swamp forests (16.8\%), Alnus glutinosa forests (16.4\%), and drier Pinus sylvestris forests (14.3\% - Aderikho \& Arnol'bik 1996). The unique massifs of 
forest bogs may be considered as main object of landscape protection in the reserve. Forest vegetation includes both southern taiga elements pine and spruce forests of undershrub-moss types, and boreo-nemoral spruce forests (Aderikho et al. 1977). Examples of the most common forest types are Pinetum pleuroziosum ${ }^{1}$ (11.5\% of forest area), Glutinosae-Alnetum caricosum (8.0\%), G. Alnetum filipendulosum (4.8\%), G.Alnetum filicosum $(3.3 \%)$, Pinetum sphagnosum $(4.1 \%)$, Piceetum oxalidosum $(2.7 \%)$.

\section{Materials and methods}

Study plots. We used 12 permanent plots of $20 \times 20 \mathrm{~m}$, according with the method described by us earlier (Yurchenko 1998; 2001b). All plots were placed in central part of the reserve (Fig. 1), taking into consideration the principle of representativeness of a forest type and ho- mogeneity of plant cover within a plot. The characterization of plots with brief description of the amount of big-size dead wood, and the sampling dates are listed below. The naming of communities is according to Matuszkiewicz (1984), and forest type nomenclature follows Yurkevich (1980).

1. Pleurozio-Pinetum (Stepanovich, 1999, unpubl.) seu Pinetum pleuroziosum, with Vaccinium vitis-idaea L., V. myrtillus L., Calluna vulgaris (L.) Hull, sparse young Picea abies (L.) Karst. trees; slightly elevated place between Razhnyanskae and Savski Mokh bogs, Domzharytsy forestry, forest sq. no. 314; 5 fallen trunks and big branches of Pinus sylvestris ca. $10 \mathrm{~cm}$ diam, 1 stump of $P$. sylvestris ca. $13 \mathrm{~cm}$ diam (code Pin1): May and Nov 1997, Jul 1998, Jun 1999.

2. Pleurozio-Pinetum seu Pinetum pleuroziosum, with Betula pendula Roth in main tree level, Juniperus communis L., Vaccinium myrtillus; slope of Razhnyanskiya Vysoty elevation, Rozhna forestry, sq. no. 245a; 4 fallen trunks of Pinus sylvestris ca. $10-15 \mathrm{~cm}$ diam, 3 fallen and standing trunks of Juniperus communis ca. $4-5 \mathrm{~cm}$ diam, 1 stump of $J$. communis (code Pin2.1): Jul 1998, Jun 1999.
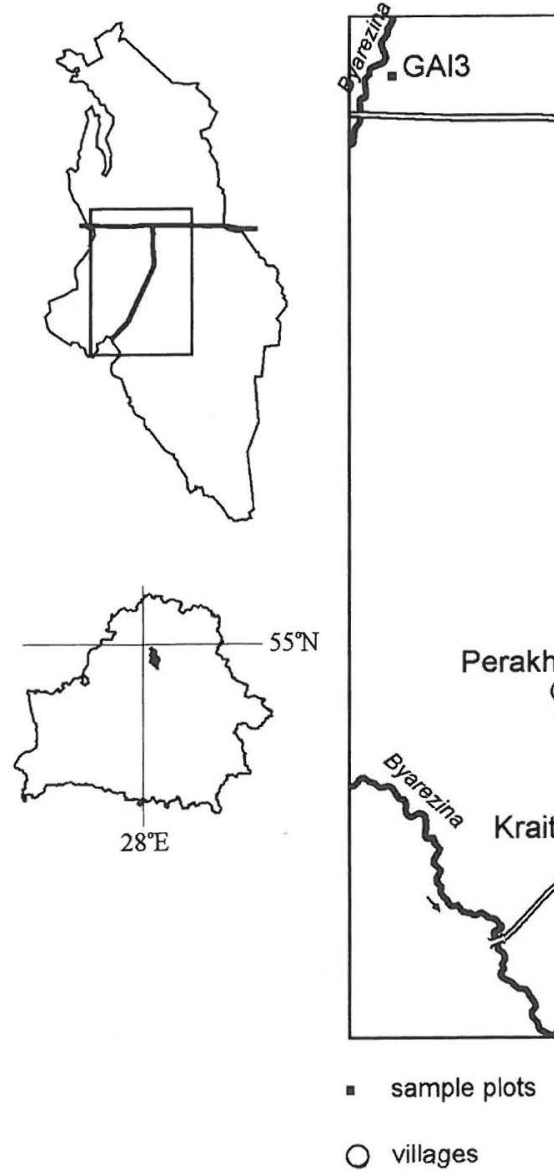

villages place of former Pastrezhzha village

$=$ roads 
3. Pleurozio-Pinetum seu Pinetum pleuroziosum, with scarce Vaccinium vitis-idaea; ibid. where Pin 2.1; 3 fallen trunks of Pinus sylvestris ca. 8-10 cm diam, 1 fallen trunk of Betula pendula ca. $8 \mathrm{~cm}$ diam, 1 stump of $P$. sylvestris and 2 stumps of $B$. pendula $c a .15 \mathrm{~cm}$ diam, 1 trunk of Juniperus communis ca. $5 \mathrm{~cm}$ diam (code Pin2.2): Jul 1998, Jun 1999.

4. Pleurozio-Pinetum seu Pinetum pleuroziosum, with Pteridium aquilinum (L.) Kuhn; plain territory near Pastrezhskae bog, Pastrezhzha forestry, sq. no. 541; 7 fallen trunks of Pinus sylvestris ca. 7-13 cm diam, 1 fallen trunk of $B$. pendula $\mathrm{ca} .7 \mathrm{~cm}$ diam (code Pin3). Sampling: Jun 2000.

5. Pino-Ledetum palustris Tx. (1955) seu Pinetum sphagnosum, with Eriophorum vaginatum L.; Razhnyanskae elevated bog, between central and marginal zone of the bog; Domzharytsy forestry, sq. no. 299; 7 standing and 3 fallen or declined trees of Pinus sylvestris ca. 5-10 cm diam (code PinS): Jul 1998, Jun 1999.

6. Querco-Piceetum Matuszkiewicz, $1952 \mathrm{em}$. Matuszkiewicz et Pol., 1955 seu Piceetum oxalidosum, with Populus tremula L., Betula pendula, Alnus incana (L.) Moench, Fraxinus excelsior L., Salix caprea L., single Acer platanoides L., Quercus robur L., and Alnus glutinosa (L.) Gaertn. in tree level, well-developed level of Corylus avellana L., with Aegopodium podagraria L.; slightly elevated territory between Razhnyanskae bog and the Buzyanka river, Domzharytsy forestry, sq. no. 284a; 1 fallen part of Fraxinus excelsior tree ca. $20 \mathrm{~cm}$ diam, 1fallen branch of Fraxinus excelsior ca. $10 \mathrm{~cm}$ diam, 3 declined and fallen trunks of Salix caprea ca. 6$12 \mathrm{~cm}$ diam, 8 fallen and standing trunks of Corylus avellana ca. $4-8 \mathrm{~cm}$ diam, 1 fallen trunk of unknown leaf tree ca. $10 \mathrm{~cm}$ diam, 1 fallen Picea abies ca. $8 \mathrm{~cm}$ diam, 1 standing tree of Alnus incana ca. $8 \mathrm{~cm}$ diam (code Pic1): May, Jun, and Nov 1997, Jul 1998, Jun 1999.

7. Vaccinio-Piceion Br.-Bl., 1938 ass. indet. or mixture of Piceetum pleuroziosum and P. myrtillosum, with Hylocomium splendens (Hedw.) Schimp. dominating in ground cover; elevated area between the Serhuch and the Byarezina rivers, Kraitsy forestry, sq. no. 404; 1 fallen tree of Pinus sylvestris ca. $25 \mathrm{~cm}$ diam, 2 standing $P$. sylvestris ca. $25 \mathrm{~cm}$ diam, 2 stumps of $P$. sylvestris ca. 20 cm diam, 2 stumps of Quercus robur ca. $50 \mathrm{~cm}$ diam, 4 declined and fallen trunks of $P$. abies ca. $5-6 \mathrm{~cm}$ in diam, 2 trunks of Juniperus communis ca. $5 \mathrm{~cm}$ diam (code Pic2): Jun 1999.

8. ?Rubo saxatilis-Populetum tremulae Korotkov, 1986 (the association is dominated by Populus tremula and probably is derivative from Calamagrostio arundinacea-Piceetum Soko ${ }^{3}$ owski, 1980) seu Tremuletum oxalidosum, with Picea abies, Rubus idaeus L., in herb cover with common Calamagrostis arundinacea (L.) Roth, Dryoptheris carthusiana (Vill.) H.P. Fuchs, and Milium effusum L.; plain territory near Pastrezhskae bog, Pastrezhzha forestry, sq. 541; 2 trunks of Betula pendula ca. $13-15 \mathrm{~cm}$ diam, 1 fallen trunk of unknown tree $c a .10 \mathrm{~cm}$ diam, 4 declined and fallen trunks and big branches of Populus tremula ca. 8-15 cm diam, 1 stump of Picea abies ca. $13 \mathrm{~cm}$ diam, 1 fallen trunk of Picea abies ca. $5 \mathrm{~cm}$ diam, 2 stumps of unknown trees ca. 15$20 \mathrm{~cm}$ diam (code Tre): Jun 2000.
9. Ribo nigri-Alnetum Sol.-Gorn., 1975 or community united features of Glutinosae-Alnetum filipendulosum, G.-Alnetum filicosum, G.-Alnetum oxalidosum, with Betula pubescens Ehrh., Picea abies, Fraxinus excelsior; lowland along the right bank of the Buzyanka river, Domzharytsy forestry, sq. no. 270b; 4 standing and fallen trunks of Picea abies 8-20 cm diam, 6 fallen and declined trunks of Alnus glutinosa ca. 10-18 cm diam, 1 fallen trunk of B. pubescens ca. $13 \mathrm{~cm}$ diam (code GAl1): Jul 1998, Jun 1999.

10. Alno-Betuletum Scamoni, 1959 seu G.-Alnetum caricosum, with Picea abies, Betula pendula, Salix pentandra L., and domination of Carcx acutiformis Ehrh. in herb level; left bank floodplain of the Serhuch river, Kraitsy forestry, sq. no. 405b; 1 declined trunk of Salix pentandra ca. $15 \mathrm{~cm}$ diam, 1 fallen tree of Picea abies ca. $10 \mathrm{~cm}$ diam, 1 stump of Alnus glutinosa ca. $12 \mathrm{~cm}$ diam, 1 fallen trunk of A. glutinosa ca. $10 \mathrm{~cm}$ diam, 5 trunks of Salix cinerea ca. $5 \mathrm{~cm}$ diam, 1 fallen trunk of Betula pendula ca. $8 \mathrm{~cm}$ diam (code GAl2): Jun 1999.

11. Alno-Betuletum (the association has features making it transitional to Carici elongatae-Alnetum Koch, 1926) seu G.-Alnetum filipendulosum, with Betula pubescens, Picea abies, Carex elongata L., Urtica dioica L.; left bank valley of the Byarezina river, high level floodplain, Rozhna forestry, sq. no. 242; 4 fallen and declined trunks of Alnus glutinosa ca. $8-10 \mathrm{~cm}$ diam, 2 fallen trunks of Picea abies ca. $13 \mathrm{~cm}$ diam, 1 stump of unknown tree $c a .15 \mathrm{~cm}$ diam, 3 standing and fallen trunks of Salix sp. ca. $5 \mathrm{~cm}$ diam (code GAI3): Jun 2000.

12. Alno-Betuletum seu Pubescenso-Betuletum thelypteridosum, with Alnus glutinosa, Salix pentandra, Carex acutiformis, and young Picea abies trees; lowland along the right bank of the Buzyanka river, Domzharytsy forestry, sq. no. $285 ; 4$ declined and fallen trunks of Alnus glutinosa ca. $10-15 \mathrm{~cm}$ diam, 3 stumps of $A$. glutinosa ca. $12 \mathrm{~cm}$ diam, 1 standing and 1 fallen tree of Salix pentandra ca. 10-13 cm diam, 2 fallen trunks of Betula pendula ca. $10-15 \mathrm{~cm}$ diam, 5 fallen and declined trunks of Salix cinerea ca. $5 \mathrm{~cm}$ diam (code PuBe): May and Jul 1997, Jun 1999.

Investigated plots are situated in natural forest communities, except of Pin3, representing Pinus sylvestris plantation. In comparison with typical forest stands PinS may be considered as a community dominated by Sphagnum spp.

The cluster analysis of the plots species lists was based on binary data matrix (presence of species on the plot 1 , absence -0 ) and carried out by means of STATISTICA 5.0 software. The unidentified taxa were compared with each other and in the case of morphological dissimilarity were added to data matrix as independent units. Czekanowski coefficient of similarity between species lists was calculated according the formula $\mathrm{C}=100 \times 2 \mathrm{w} /$ $(\mathrm{a}+\mathrm{b})$, where $\mathrm{a}$ and $\mathrm{b}-$ total number of species in community 1 and 2, w - number of species common for both communities.

The collection material is preserved in V.F. Kuprevich Institute of Experimental Botany Herbarium, section "Fungi", Minsk (MSK-F).

The nomenclature of fungi and taxa delimitation mostly follow Hansen and Knudsen (1997) and the authors of species are not repeated here. 
Table 1. Distribution of common species of corticioid fungi in sample biocoenoses of Byarezinski Biosphere Reserve, arranged along the gradient of soil humidity.

Sample plot code

\begin{tabular}{|c|c|c|c|c|c|c|c|c|c|c|c|c|c|}
\hline No. & Species & Pin 1 & Pin 2.1 & Pin2.2 & Pin3 & Pic2 & Tre & Picl & GAl3 & GAl1 & GAl2 & $\mathrm{PuBe}$ & PinS \\
\hline 1 & Amphinema byssoides & + & + & + & + & + & & + & + & + & + & + & \\
\hline 2 & A. epiphylla complex & + & + & + & + & & + & + & & & & + & + \\
\hline \multirow[t]{2}{*}{3} & Botryobasidium candicans & & & & & & & & & & & & \\
\hline & (and anamorph stage Haplotrichum capitatum) & + & + & + & + & & & & & & & + & \\
\hline 4 & B. leave & & & & & & & & + & + & + & + & \\
\hline 5 & B. subcoronatum & + & + & + & + & & + & & + & + & & & \\
\hline 6 & Ceraceomyces microsporus & + & + & + & & + & + & & & & & & \\
\hline 7 & Hymenochaete tabacina & & & & & + & + & & + & & + & + & \\
\hline 8 & Hyphoderma praetermissum complex & + & + & & + & + & + & + & & + & + & + & \\
\hline 9 & H. setigerum & & & & & & + & & + & + & + & + & \\
\hline 10 & Hyphodontia barba-jovis & & & & & & + & + & + & & + & & \\
\hline 11 & H. breviseta, $H$. cf. breviseta & + & + & + & + & + & + & & & + & & & \\
\hline 12 & H. radula & + & & & & & + & + & + & & + & + & \\
\hline 14 & H. subalutacea & + & + & + & & & & & & & & + & \\
\hline 15 & Peniophora cinerea & & & & + & + & & + & + & + & & + & \\
\hline 16 & P. incarnata & & & & & & & + & + & + & & + & \\
\hline 17 & Phlebiella pseudotsugae, Ph. cf. pseudotsugae & + & + & + & & + & & & & & & & + \\
\hline 18 & Ph. sulphurea & + & + & + & + & + & + & + & & & & & \\
\hline 19 & Scopuloides hydnoides & & & & & & & + & + & & + & + & \\
\hline 20 & Sistotrema brinkmannii & & & & & + & & + & & & + & + & \\
\hline 21 & Tomentella lapida, $T$. cf. lapida & & + & & + & + & & & & + & & & \\
\hline 22 & T. punicea, T. cf. punicea & & + & & + & + & + & & & + & + & + & \\
\hline 23 & Trechispora microspora & + & + & & + & + & & + & + & & + & + & + \\
\hline 24 & Tubulicrinis glebulosus & & & & & + & & + & + & & & + & \\
\hline 25 & T. subulatus & + & + & + & + & + & & & & & & & + \\
\hline
\end{tabular}




\section{Results and discussion}

General distribution. Altogether 135 species of corticioid fungi were registered in the reserve, and $105(78 \%)$ of them were found on the sample plots studied. Twenty-five species $(18.5 \%)$ found on 4 or more plots, are treated as commonly distributed in the reserve (Tab. 1). Moreover, these species were registered as common in a number of other studies sites of Belarus. Four taxa, Amphinema byssoides, Athelia epiphylla complex, $\mathrm{Hy}$ phoderma praetermissum complex (see Eriksson \& Ryvarden 1975), and Trechispora microspora inhabit the widest range of biotopes. They were observed on $8-10$ plots, and can be referred to eurytopic species. The genera Hyphodontia (on all plots) and Tomentella (on all plots except PinS) are the most constant in forest coenoses. These two genera, together with Athelia and Botryobasidium, are the leading elements in most forest communities. The genera Hyphodontia, Peniophora, and Tomentella have the highest species diversity on study plots. There are 4-5 species of Hyphodontia in Pin1, Pin2.2, Pic1, Tre, GA11, PuBe, 4 species of Peniophora in GAl1, and 4-5 species of Tomentella in Pic2 and PuBe, respectively. The genera Athelia, Botryobasidium, Ceraceomyces, Hyphoderma, Stereum, and Trechispora include up to 3 species per plot.

Comparison of species composition in sample biocoenoses. Studied communities have different species diversity (Tab. 2) explained by the com- plex of factors. The number of species unique for a plot reflects the specific structure of given community. It also shows the mosaic distribution of fungal populations which not always coincides with distribution of biotopes suitable for species inhabitation. The most specific fungus flora is on conifer-dominated plots (Tab. 2).

In order to group sample communities a cluster analysis based on dissimilarity between species lists was carried out (Fig. 2). The coefficients of similarity between communities are presented in Tab. 3.

Two main clusters are revealed from both dendrograms: (1) Pinus sylvestris communities and (2) deciduous swamp forest communities, composed of Alnus glutinosa and Betula pubescens, with admixture of Picea abies. The highest similarity is between plots belonging to the same association: three plots of Alno-Betuletum (GAl2, $\mathrm{GAl} 3, \mathrm{PuBe}) \mathrm{C}=42-54$, and four plots of Pleurozio-Pinetum (Pin1, Pin2.1, Pin2.2, Pin3) $\mathrm{C}=38-57$ (Tab. 3). The similarity between Pin 1 and Pin 2.2 disposed $5 \mathrm{~km}$ apart is more than between the neighbouring plots Pin2.1 and Pin2.2. The plots Pin1 and Pin2.2 have very similar ground cover and tree level composition. The biocoenoses GAl2 and GAl3 differ in herb cover and soil humidity, but have very similar tree level composition. Thus, we can observe correlation between vascular plants complex (presumably woody plants) and corticioid fungi complex in studied biocoenoses.

Tab. 2. Corticioid fungi species diversity and relative amount of dead wood in sample biocoenoses.

\begin{tabular}{|c|c|c|c|c|c|c|c|c|c|c|c|c|}
\hline Plot code & Pin 1 & Pin2.1 & Pin 2.2 & Pin 3 & PinS & Pic1 & Pic2 & Tre & Gal1 & Gal2 & Gal3 & $\mathrm{PuBe}$ \\
\hline $\begin{array}{l}\text { Total number } \\
\text { of species }\end{array}$ & 25 & 29 & 21 & 16 & 6 & 46 & 29 & 17 & 31 & 20 & 21 & 32 \\
\hline $\begin{array}{l}\text { Number of } \\
\text { species unique } \\
\text { for the plot; }\end{array}$ & 3 & 11 & 6 & 2 & 1 & 18 & 7 & 0 & 6 & 2 & 4 & 4 \\
\hline $\begin{array}{l}\text { Relative } \\
\text { amount of } \\
\text { dead wood } \\
\text { (ranked in } \\
\text { 3-grades } \\
\text { scale) }\end{array}$ & 2 & 2 & 2 & 2 & 1 & 3 & 3 & 2 & 3 & 2 & 2 & 3 \\
\hline
\end{tabular}

*Finds outside of study plots omitted. 


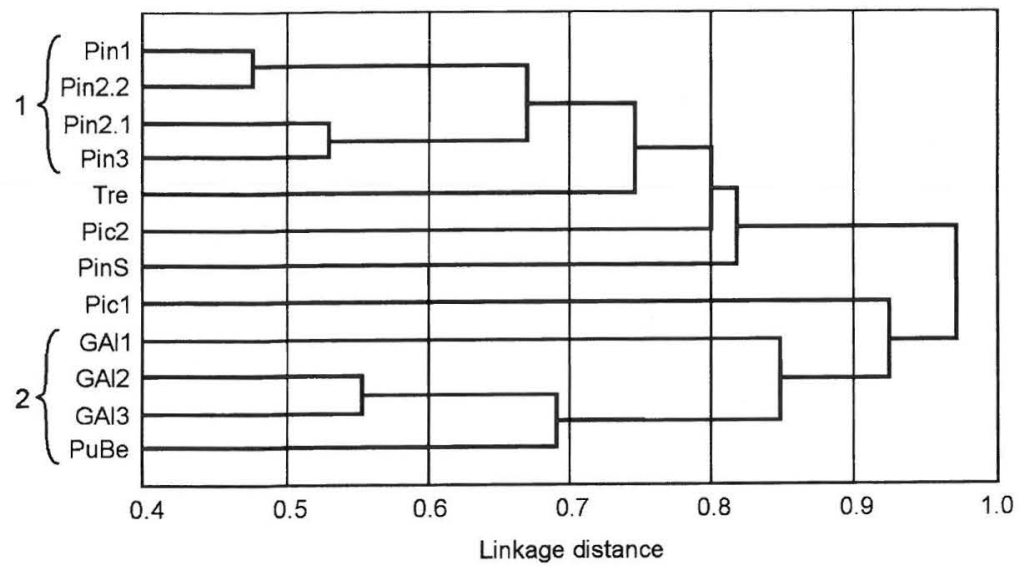

Fig. 2. Dendrograms illustrating the clustering of studied forest biocoenoses on the base of corticioid fungi species composition. Distance: 1Pearson coefficient of correlation. A - dendrogram built using UPGMA algorithm. B dendrogram built using complete linkage algorithm.

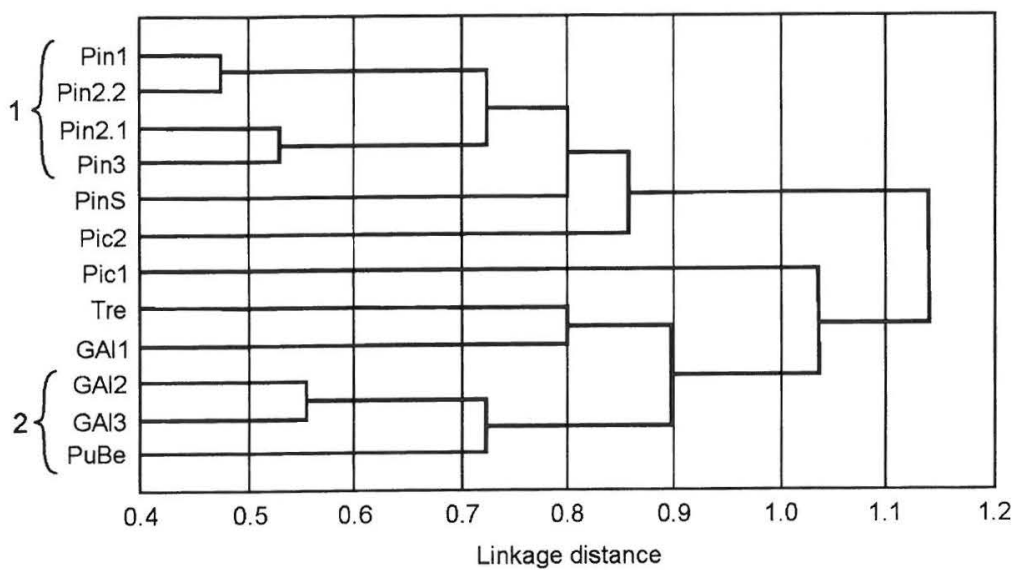

A

B

Tab. 3. Similarity (Czekanowski coefficient, \%) between corticioid fungi species lists of the sample plots. The highest values are given in bold.

\begin{tabular}{lccccccccccc}
\hline Plot code & Pin1 & Pin2.1 & Pin2.2 & Pin3 & PinS & Pic1 & Pic2 & Tre & GAl1 & GAl2 & GAl3 \\
\hline PuBe & 32 & 23 & 15 & 29 & 16 & 35 & 30 & 33 & 41 & $\mathbf{4 6}$ & 42 \\
GAl3 & 22 & 12 & 10 & 22 & 7 & 32 & 20 & 26 & 31 & $\mathbf{5 4}$ & \\
GAl2 & 18 & 12 & 5 & 17 & 8 & 33 & 20 & 32 & 27 & & \\
GAl1 & 25 & 23 & 15 & 30 & 5 & 28 & 30 & 33 & & & \\
Tre & 43 & 35 & 32 & 42 & 9 & 25 & 26 & & & & \\
Pic2 & 37 & 38 & 28 & 44 & 17 & 24 & & & & & \\
Pic1 & 25 & 24 & 15 & 22 & 11 & & & & & & \\
PinS & 26 & 23 & 22 & 27 & & & & & & & \\
Pin3 & 39 & $\mathbf{5 3}$ & 38 & & & & & & & & \\
Pin2.2 & $\mathbf{5 7}$ & 44 & & & & & & & & & \\
Pin2.1 & $\mathbf{5 2}$ & & & & & & & & & & \\
\hline & & & & & & & & & & &
\end{tabular}


A representative for the boreo-nemoral spruce community, Pic1, has species which draws it together with cluster (2) of deciduous swamp forests. At the same time it is rather far from a boreal spruce community (Pic2). Pine-spruce community, Pic2, is united with cluster (1), since it is evidently a derivative of pine forest. Both Pic2 and representatives of Pleurozio-Pinetum belong to a group of boreal undershrub-moss coniferous forests. Corticioid fungi assemblage of spruceaspen community (Tre) has an intermediate position remote from spruce communities, but has some similarity with cluster (2) and more with cluster of pine forests (Fig. 2).

Moisture is one of the most important microclimatic factors affecting the species distribution of corticioid fungi. Since most wood-rotting fungi inhabit dead wood on ground, soil humidity is a leading condition determining assemblages of species. The location of biotopes on higher or lower relief levels and the nature of underlying ground finally determine the soil humidity. The studied plots are distributed along the gradient of soil humidity in accordance with:

Pin1, Pin2.1, Pin2.2, Pin3 < Pic2, Tre $<$ Pic $1<$ GAl3 < GAl1, GAl2, PuBe, PinS

The association Pleurozio-Pinetum occupy moderately dry, well drained ecotopes in contrast with communities GAl1, GAl2, PuBe, occupying extra humid ecotopes with water level constantly above ground surface. However, pronounced hillocks around standing trees in the last biotopes are moderately dry microhabitats for fungi on dead wood. Soil humidity and light regime determine the per cent of xero- meso- and hygrophilous fungal species in a community. In dry pine forests almost all corticioid fungi develop basidiomata on lower side of fallen wood, in litter, and under moss cover (good examples are Amphinema byssoides, Phanerochaete sanguinea, Phlebiella pseudotsugae, Ph. sulphurea). In deciduous and mixed swamp forests the fungal complex include both xeromesophilous species on stillattached dead twigs (Byssomerulius corium, Corticium roseum, Hymenochaete tabacina, Peniophora cinerea, $P$. incarnata, $P$. violaceolivida) and mesohygrophilous species on fallen wood in contact with water surface in depressions (Scopuloides hydnoides, Subulicystidium longisporum, Tomentella).

The peat bog plot (Pino-Ledetum, PinS) has the minimal species diversity and abundance of corticioid fungi. There are certain factors suppressing the development of wood-rotters. On the first hand, still-attached dead twigs and trunks are sun-exposed and dried by wind due to sparse and draft pine stand. On the other hand, fallen wood is exposed to high acidity of moss cover upper layer which may be in upper peat layer sometimes as low as pH 2.6 (Boch \& Mazing 1979). The species composition is quite remote from all other types of biocoenoses, but has some similarity with non-swamp pine forests (Fig. 2) due to the presence of Phlebiella cf. pseudotsugae and Tubulicrinis subulatus.

Characteristic species assemblages in different types of biocoenoses. A number of species have a wide ecological amplitude, and colonize different biotopes from dry hill tops to swampy depressions (Tab. 1). Some species, however, have a narrower amplitude. In this study we observed rather stable combinations of species, or species assemblages.

Southern taiga, non-boggy pine forests (Pin1, Pin2.1, Pin2.2, Pin3) with Vaccinium myrtillus, $V$. vitis-idaea, Calluna vulgaris, Pleurozium schreberi (Brid.) Mitt., Dicranum polysetum Sw., Hylocomium splendens have a quite stable assemblage: Amphinema byssoides-Athelia epiphylla complex-Botryobasidium candicans-B. subcoronatum-Phlebiella sulphurea-Tubulicrinis subulatus. The most constant and abundant species here are Amphinema byssoides and Phlebiella sulphurea, observed in pine forests all over Belarus. Our observations together with the data on Estonia (Parmasto \& Parmasto 1997), Leningrad region (Bondartseva et al. 1999), and Finland (Bondartseva et al. 1998) indicate that $A$. byssoides, Botryobasidium subcoronatum, and Ph. sulphurea are evidently the most common species in coniferous forests in boreal and boreonemoral zones of Europe. They inhabit different kinds of fallen wood immersed in moss cover, and also occur on litter under mosses and logs (presumably A. byssoides and Ph. sulphurea). Other species typical to pine or spruce-pine forests of undershrub-moss types are: Athelia cf. arachnoidea, Ceraceomyces microsporus, Hyphoderma praetermissum complex, Hyphodontia breviseta, H. subalutacea, Phlebiella pseudotsugae, and Trechispora microspora. Common in conifer forest ecosystems and sometimes abundant are Sistotremastrum suecicum and Phanerochaete sanguinea. The most species-rich genera in pine 
forests are Botryobasidium, Hyphodontia, and Trechispora, with 2-5 species per plot.

Southern taiga, pine-spruce community (Pic2) has elements common also in pine forests - Ceraceomyces microsporus, Phlebiella pseudotsugae, and Tubulicrinis subulatus. A remarkable feature of Pic2 is the abundance of Tomentella - 5 species, among which $T$. punicea and T. lapida were recorded as dominating. These data together with the registering of 4 Tomentella species in Pic1 indicate that diversity of resupinate thelephoroid fungi is high in spruce forests. The wood-litter fungus Piloderma byssinum is rare in the reserve, and was found only in Pic2, in contrast to its abundance in more northern regions (e.g. Estonia - Parmasto 1965; Parmasto \& Parmasto 1997). Tomentellas and $P$. byssinum, which are commonly confined to forest litter and strongly decayed wood, are known as facultative mycorrhizal fungi.
Boreo-nemoral mixed spruce forests with rich herb cover is represented by plot Pic1. This plot is obviously a unique forest ecosystem in the area, containing 8 tree species and 1 shrub species on $400 \mathrm{~m}^{2}$ area, and having the richest diversity of corticioid fungi (Tab. 2, 4). Some species have their only records on this plot in the reserve and even the whole Belarus (Tab. 4). Shallow ground depressions which accumulate rain and snow, and the shadow of Picea abies and Corylus avellana canopy form moderately moist microclimate. The elements connecting Pic1 with swamp forests are Scopuloides hydnoides, Subulicystidium longisporum, and Tomentella stuposa. The community also includes elements typical to boreal coniferous forests: Phlebiella sulphurea and Trechispora farinacea.

Deciduous and mixed swamp forests dominated by Alnus glutinosa and Betula pendula have

Tab. 4. Example of a plot species list. Corticioid fungi registered on $400 \mathrm{~m}^{2}$ square plot "QuercoPiceetum" (Pic1), with the value of their relative abundance:*

\begin{tabular}{llll}
\hline 1. Amphinema byssoides & 2 & & \\
2. Athelia epiphylla complex & & 24. Ph. velutina & 2 \\
(incl. A. salicum) & 2 & 25. Phlebia fuscoatra & 2 \\
3. Botryohypochnus isabellinus & 1 & 26. Ph. rufa & $2+$ \\
4. Brevicellicium olivascens & $2+$ & 27. Phlebiella sulphurea & 2 \\
5. Ceraceomyces eludens & 1 & 28. Radulomyces confluens & 2 \\
6. C. aff. serpens & 2 & 29. Scopuloides hydnoides & 1 \\
7. Ceratobasidium sp. & 1 & 30. Sistotrema brinkmannii & 1 \\
8. Cylindrobasidium evolvens & 2 & 31. S. oblongisporum & 1 \\
9. Gloeocystidiellum porosum & 1 & 32. Sistotremastrum niveocremeum & 1 \\
10. Hymenochaete cinnnamomea & 2 & 33. Steccherinum fimbriatum & 2 \\
11. Hyphoderma definitum & $1+$ & 34. Stereum hirsutum & 2 \\
12. H. praetermissum complex & 2 & 35. S. rugosum & 2 \\
13. Hyphodontia barba-jovis & 2 & 36. Subulicystidium longisporum & 1 \\
14. H. crustosa & 3 & 37. Tomentella cf. atramentaria & 1 \\
15. H. radula & 1 & 38. T. badia & $1+$ \\
16. H. sambuci & 2 & 39. T. galzinii & $1+$ \\
17. Hyphodontia sp. & 2 & 40. T. stuposa & 1 \\
18. Hypochnicium erikssonii & $1+$ & 41. Trechispora farinacea & 1 \\
19. Peniophora cinerea & 3 & 42. T. microspora & 2 \\
20. P. erikssonii & 1 & 43. Tubulicrinis glebulosus & 3 \\
21. P. incarnata & 3 & 44. Vuilleminia comedens & 1 \\
22. P. polygonia & 1 & 45. Unidentified sp. 1 (MSK 4081) & 1 \\
23. Phanerochaete laevis & 2 & 46. Unidentified sp. 2(MSK 4908) & 1 \\
& & &
\end{tabular}

*determined according to original scale as approximate sum area of basidiomata plus their frequency: 1 - very smallsized or small-sized, single or occasional fruitbodies, 2 - medium-sized, moderately conspicuous or regularly meeting fruitbodies, 3 - significant, big or common fruitbodies; + - single known site for the species in the reserve; ++ - single known site for the species in Belarus. 
typical species assemblage: Amphinema byssoides-Botryobasidium laeve-Hyphoderma setigerum. A. byssoides is rather scarce here, but highly constant and develops on fallen wood on hillocks associated with bases of standing trunks. The species characterists are also: Hymenochaete tabacina, Hyphoderma praetermissum complex, Hyphodontia barba-jovis, H. radula, Peniophora cinerea, $P$. incarnata, Scopuloides hydnoides, Trechispora microspora.

The species assemblage of spruce-aspen community (Tre) has elements common to both conif- erous forests (Ceraceomyces microsporus, $\mathrm{Hy}$ phodontia breviseta, Phlebiella sulphurea) and swamp alder forests (Hyphoderma setigerum).

Dependence of complex of corticioid fungi on species composition of woody plants in biocoenosis. Species of trees and shrubs play different roles as hosts for wood decomposing fungi (Fig. 3). In general, species diversity of woodinhabiting fungi in biocoenosis increases with the number of woody plants.

In Pleurozio-Pinetum the taxonomical diversity of corticoid fungi is affected by the presence

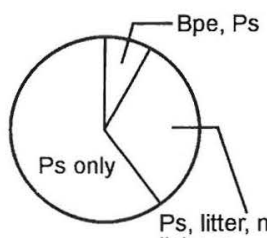

Pin1

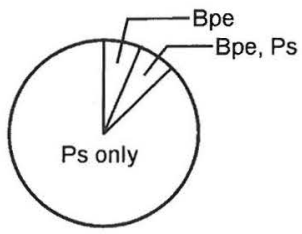

Pin3

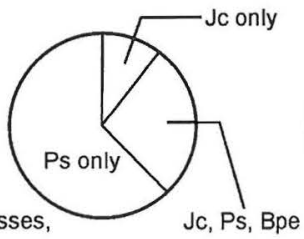

Pin2.1

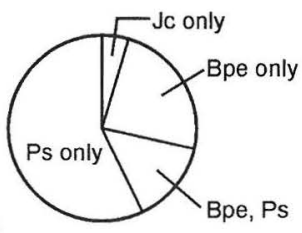

Pin2.2

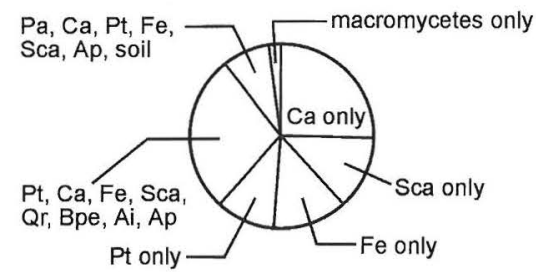

Pic1
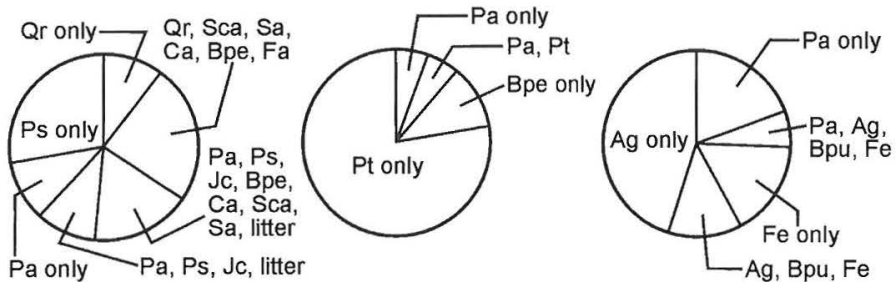

Pic2

Tre

GAl1

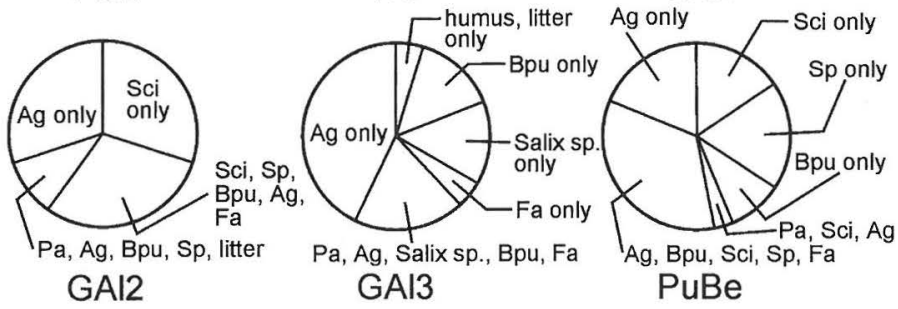

Fig. 3. Diagrams showing species composition of corticoid fungi in sample communities in regard to substratum preferences. The sectors reflect per sent of species inhabiting wood, bark, or occasionally fallen leaves of: Ai - Alnus incana, Ag - Alnus glutinosa, Ap - Acer platanoides, Bpe - Betula pendula, Bpu - Betula pubescens, Ca - Corylus avellana, $\mathrm{Fa}$ - Frangula alnus Mill., Fe - Fraxinus excelsior, Jc - Juniperus communis, $\mathrm{Pa}-$ Picea abies, Ps - Pinus sylvestris, Pt - Populus tremula, Qr - Quercus robur, Sa - Sorbus aucuparia L., Sca - Salix caprea, Sci - Salix cinerea, Sp - Salix pentandra. 
of Betula pendula and Juniperus communis. Both hosts increase the number of species in the community: Ceraceomyces borealis, Peniophora cinerea, and Tomentella fuscocinerea were registered on Betula pendula; Ramaricium alboochraceum and Vesiculomyces citrinus were registered on Juniperus communis). The influence of Betula pendula is small if only occasional trees are present (Pin1, Pin3). Besides wood as main nutritive substratum, the fungal basidiomata and vegetative hyphae can occupy herb debris, fallen leaves, dead and living lichen thalli, and dead and living moss sprouts (Yurchenko 2001a). Example of such species on several substrata in pine forests is shown in Fig. 3 for Pin 1.

The most complex structure of trophic connections is found in broadleaf-spruce forests and coniferous forests with a mixture of deciduous trees (Pic 1, Pic2). In Pic 1 only 8.5\% of corticioid species were registered on the dominant tree species Picea abies, and $21 \%$ on co-dominant tree Populus tremula, respectively. On both deciduous and coniferous hosts $6.5 \%$ of species were registered, and $85 \%$ were collected on deciduous tree and shrub species only. The richest assemblage was found on Corylus avellana - 49\% of species grow on hazel and $25.5 \%$ grow solely on this host. Actually $C$. avellana defines the "figure" in Pic1, together with Fraxinus excelsior (25.5\% of species, $13 \%$ on this host only), and Salix caprea (19\% of species, $13 \%$ on this host only). In such communities $C$. avellana is the most accessible substratum for corticioid fungi due to a large amount of short-living trunks, making bulk of dead wood. Also the considerable length (and thus, area) of trunks and branches, and possibly also the chemical peculiarities of the wood are suitable for many species. In Pic2 the fungus flora on angiosperms constitutes more than half of the species and includes $45 \%$ of species which grow on angiosperms only. Other important factor increasing the richness of saprobic xylotrophic fungi is the quantity of fallen wood, especially windfalls, which are particularly common in mixed spruce forests (Tab. 2).

In Alno-Betuletum a great number of fungi grow on Salix species, especially in $\mathrm{PuBe}$, where $44 \%$ of species were found on $S$. pentandra, and $19 \%$ on this substratum only; $31 \%$ of the species were recorded on S. cinerea L., and $16 \%$ of on this host only. On Alnus glutinosa and Betula pubescens in PuBe $41 \%$ and $28 \%$ of species were accordingly registered. Besides willows, the corticioid assemblage in swamp forests is determined by Alnus glutinosa. In comparison with alder, Betula pubescens has the assemblage of less specialized species.

Distribution of highly specialized species. There is a tendency in evolution of wood-inhabiting Basidiomycetes to specialize on single or several related hosts (Hallenberg 1991: 102). Thus the distribution of fungi is determined by the distribution of host. The most noticeable example is Peniophora junipericola, which is connected with great Juniperus communis populations in Estonia (Parmasto 1992). An other example is Peniophora quercina in Belarus. It is associated with oak forests or sites with sufficient number of quite mature Quercus robur trees, and could consequently not be observed on the study plots in the reserve. In Byarezinski Reserve the species restricted to communities with sufficient host populations are: Amylostereum laevigatum (Juniperus communis), Corticium roseum and Peniophora violaceolivida (Salix spp.), Peniophora erikssonii (Alnus spp.), P. limitata (Fraxinus excelsior), and P. polygonia (Populus tremula).

According to this study the essential factors determining the distribution and coenotic preferences of corticioid fungi are the richness of woody plants species, coniferous/deciduous hosts proportion, soil humidity, and quantity of fallen wood increasing in older forests. Oligotrophic bogs with pine stands are exception from this general rule. The ecological conditions in broadleaf-spruce forests are the best for development of a rich fungus flora.

Aknowledgements: I am grateful to Dr. N. Hallenberg (University of Göteborg, Sweden) for critical review of the manuscript and help in identification of some species. Sincere thanks go to Dr. H. Kotiranta (University of Helsinki, Finland) for critical remarks on the article, to Hbl. Dr. I. M. Stepanovich (Institute of Experimental Botany, Minsk) for kind identification of forest association according to floristic principle, and to Dr. I.V. Zmitrovich (V.L. Komarov Botanical Institute, St. Petersburg) for kind revision of some herbarium specimens. I am also thankful to scientists of Byarezinski Biosphere Reserve, Mr. Yu. Bogutskii and Mrs. T. Bogutskaya for giving the data on forest types distribution and for assistance in my field researches. 


\section{References}

Aderikho, V.S., Bandurin, V.I., Golod, D.S. et al. 1977: Karta rastitel'nosti Belorusskoi SSR (Map of Byelorussian SSR vegetation) / Eds. I.D. Yurkevich, D.S. Golod. - Glavnoe upravlenie geodezii i kartografii pri Sovete Ministrov SSSR (Geodesy and Mapping Chief Direction at the Ministers Soviet of USSR), Moscow. (In Russian.)

Aderikho, V.S. \& Arnol'bik, V.M. 1996: Forests. In: Stavrovsky, D.D., Kovalev, A.A. (eds.) Berezinsky Biosphere Reserve: Science-popular edition. - Izdatel'stvo Belorusskaya Entsiklopediya (Byelorussian Encyclopaedia), Minsk. Pp. 48-74. (Russian with English summary.)

Boch, M.S. \& Mazing, V.V. 1979: Ekosistemy bolot SSSR (Bog ecosystems of USSR). - Izdatel'stvo Nauka, Leningrad. 187 pp. (In Russian.)

Bondartseva, M.A., Lositskaya, V.M. \& Zmitrovich, I.V. 1998: Aphyllophoroid fungi of old and primeval forests in the Kotavaara site of North Karelian biosphere reserve. - Folia Cryptog. Estonica 33: 19-24.

Bondartseva, M.A., Zmitrovich, I.V. \& Lositskaya, V.M. 1999: Aphyllophoroid and heterobasidial macromycetes of the Leningrad region. In: Biodiversity of the Leningrad region (Algae, Fungi, Lichens, Bryophytes, Invertebrates, Fishes and pisciformes). - St. Petersburg Univ., St. Petersburg. Pp. 141-173. (Russian with English summary.)

Dzyaments'eu, V.A. 1975: Fizika-heahrafichnae rayanavanne (Physiographic partition of the territory). In: Belaruskaya Savetskaya Entsyklapedyya. Tom 12 (Belarusian Soviet Encyclopaedia. Vol. 12). - Vydavetstva BelSE, Minsk. - Pp. 51 - 52. (In Belarusian.)

Eriksson, J. \& Ryvarden, L. 1975: Hyphoderma praetermissum. In: The Corticiaceae of North Europe. Vol. 3: Coronicium - Hyphoderma. - Fungiflora, Oslo. Pp. 504-511.

Golovko, A.I. \& Komarova, E.P. 1972: Derevorazrushayushchie griby Berezinskogo zapovednika iz por. Aphyllophorales (Wood-rotting Aphyllophorales of Berezinskii Reserve). In: Berezinskii zapovednik: Issledovaniya, tom. 2 (Berezinskii Reserve: Researches, vol. 2). - Izdatel'stvo Uradzhai, Minsk. Pp. 110 119. (In Russian.)

Hallenberg, N. 1991: Speciation and distribution in Corticiaceae (Basidiomycetes). - Pl. Syst. Evol. 177: 93 110.

Hansen, L. \& Knudsen, H. (eds.) 1997: Nordic macromycetes. Vol. 3: Heterobasidioid, aphyllophoroid, and gastromycetoid Basidiomycetes. - Nordsvamp, Copenhagen. $444 \mathrm{pp}$.
Jülich, W. \& Stalpers, J.A. 1980: The resupinate nonporoid Aphyllophorales of the temperate northern hemisphere. - Verh. Kon. Ned. Akad. Wetensch., Afd. Natuurk. II 74. - North-Holland Publ. Co., Amsterdam, Oxford, N.Y. 335 pp.

Matuszkiewicz, W. 1984: Przewodnik do oznaczania zbiorowisk roœlinnych Polski. Wyd. drugie. - PWN, Warszawa. $298 \mathrm{~s}$.

Parmasto, E. 1965: Section Byssina of the genus Athelia (Corticiaceae) in the U.S.S.R. In: Problemy izucheniya gribov i lishainikov (Problems of fungi and lichens investigation: Materials of IV symposium of Baltic mycologists and lichenologists). - Tartu. Pp. 129133. (Russian with English summary.)

Parmasto, E. 1992: Peniophora junipericola (Aphyllophorales, Corticiaceae): distribution and spore variability. - Karstenia 32: 13-16.

Parmasto, E. \& Parmasto, I. 1997: Lignicolous Aphyllophorales of old and primeval forests in Estonia. 1. The forests of northern Central Estonia with a preliminary list of indicator species. - Folia Cryptog. Estonica 31: 38-45.

Yurchenko, E.O. 1998: Kortitsioidnye griby v biotsenozakh Berezinskogo biosfernogo zapovednika, Belarus (Corticioid fungi in biocoenoses of Berezinskii Biosphere Reserve, Belarus). In: Problems of the botanical sciences at the boundary of XX and XXI centuries: Abstracts, presented to the II (X) Congress of the Russian Botanical Society, vol. 2. - Komarov Botanical Institute, St.-Petersburg. Pp. 44-45. (In Russian.) Yurchenko, A.... 2001a: Corticioid fungi on mosses in Belarus. - Mycena 1 (1): 71-91.

Yurchenko, E.O. 2001b: Vyyavlenie vidovogo raznoobraziya kortitsioidnykh gribov v lesnykh biotsenozakh: metodicheskie aspekty (Investigation of the species diversity of corticioid fungi in forest biocoenoses: Methodical aspects). In: Materialy Vseukrainskoi konferentsii studentiv, aspirantiv ta molodykh vchenykh "Bioriznomanittya pryrodnykh i tekhnohennykh bitopiv Ukrainy". Chast' 1 (Materials of All-Ukraine conference of students, postgraduates, and young scientists "Biodiversity of natural and technogenic biotopes of the Ukraine". Part 1). - Donetsk National University, Donetsk. Pp. 260-264. (Russian with short English summary.)

Yurkevich, I.D. 1980: Vydelenie tipov lesa pri lesoustroitel'nykh rabotakh: Vspomogatel'nye tablitsy (The distinguishing of the forest types during forest arrangement works: The auxiliary tables). 3rd ed. Izdatel'stvo Nauka i tekhnika, Minsk. 120 pp. (In Russian.) 